\title{
Evaluation of the Biodegradation of Different Types of Lubricant Oils in Liquid Medium
}

\author{
Paulo Renato Matos Lopes and Ederio Dino Bidoia* \\ Departamento de Bioquímica e Microbiologia; Campus de Rio Claro; Instituto de Biociências; Universidade \\ Estadual Paulista “Júlio de Mesquita Filho”; Av. 24A, 1515; 13506-900; Rio Claro - SP - Brasil
}

\begin{abstract}
The aim of this work was to study the biodegradation of different types of automotive lubricant oils adapted to the aqueous medium using a base inoculum and an aqueous inoculum. Four treatments were carried out in two consecutive and similar experiments: T1 (control); T2 (half-synthetic oil); T3 (mineral oil); T4 (used oil). The results showed the following decreasing order of $\mathrm{CO}_{2}$ production in the Bartha and Pramer respirometers: T4 > T2 $>$ T3 > T1. Thus, the used lubricant oil showed with highest biodegradability, followed by the half-synthetic one and the mineral oil. It was also observed that the mineral lubricant presented a longer period of adaptation compared to the half-synthetic one.
\end{abstract}

Key words: biodegradation, lubricant oil, respirometry, liquid medium

\section{INTRODUCTION}

The water resources are becoming scarcer due to increasing demand, population growth, wastefulness, indiscriminate use in the cities, agriculture and industry. Together with these factors, the quality of waters poses intense risks near to the urban areas. The concerns about the conservation of the environment have grown in last years, due to the conscience in the societies on the importance of the environment quality as a base to preserve the life of future generations.

In the whole world, the oil represents the main source of fuel and its processing leads potential environment pollution. Great amounts of residues are formed during its production, transport and refining (Crivelaro, 2005). Bartz (1998) reported that about $1.0 \%$ of all oil consumed is used to produce lubricants.

The lubricant oil discarded in the nature is a cause of concern due to a non-quantified impact, because of its potential chronic damage to the human health. It is impossible to avoid totally the emission of this effluent directly in the environment (Wright et al., 1993), and the impact caused a decreasing of microbiota biodiversity (Atlas et al., 1991).

The pollution generated by discarding a ton of used oil per day is equivalent to the domestic sewer of 40000 inhabitants, besides the fact that one liter of this substance is able to deplete the oxygen of a million liters of water. Also, the indiscriminate burning of the used lubricant oil, without previous treatment of desmetalization, generates significant metallic oxides emissions,

Author for correspondence: ederio@rc.unesp.br 
besides other toxic gases, as the dioxin and sulphur oxides (Ambientebrasil, 2006).

In this context, Burns et al. (1994) had observed that the lubricant oil could persist in the environment for more than six years in some ecosystems, causing chronic problems for the biota. Even under the most controlled laboratorial conditions, the complete metabolism of the oil by microorganisms takes weeks to months (Atlas, 1995). Thus, the characterization of the environmental behavior and the lubricant properties are bases to the development of new fluids, and the biodegradability is the most important aspect when the substance is discarded in the environment (Eisentraeger et al., 2002).

Amongst the lubricant oils components, the polyaromatic hydrocarbons have been identified as carcinogenics by the International Agency for Research on Cancer (1983) and, as the mineral oils present a bigger concentration in its composition, they also become more harmful, compared with the synthetic ones, when displayed to the living beings, including humans (Cotton et al., 1977).

There is a clear advantage of the synthetic oil over the mineral one, because, during its manufacture, the synthetic composition can be controlled and the oil can be absent of polyaromatic hydrocarbons. Other advantages are a bigger biodegradability, greater resistance to high temperatures and high performance (Wright, 1992). On the other hand, mineral lubricant oils do not have a big biodegradability in soil and, therefore, they can cause serious environment problems when they are not properly disposed (Ambientebrasil, 2006).

Rosato (1997) emphasized that to attenuate the environmental effect caused by water pollution by hydrocarbons derived from oil, as lubricant oils, the bioremediation was less aggressive and more adjusted to maintain the ecological balance. The recovery by bioremediation of an environmental contaminated area with hydrocarbons demands a proper study of the organic load degradability of these residues by the soil microorganisms. Hence, the $\mathrm{CO}_{2}$ release method usually is used to measure this activity (Barhouch; Fortes-Neto, 2004).

The Technical Standard L6.350 issued by CETESB (1990) considers the measure of $\mathrm{CO}_{2}$ produced in the Bartha and Pramer respirometers. The respirometric assay consists of the determination of the $\mathrm{CO}_{2}$ generated by the degradation process of organic substances. Respirometric method is a good alternative to monitor the biodegradation of industrial effluents as demonstrated by Régis and Bidoia (2005) and Oliveira et al. (2007). These studies showed the respirometric efficiency in monitoring aerobic microbiological activity in industrial wastes treatment.

Thus, the aim of the present work was to study the biodegradation of different types of automotive lubricant oils (mineral, half-synthetic and used oil) in aqueous medium, simulating an aquatic environment. Bartha and Pramer respirometric method (1965) was used, following the Technical Standard L6.350 issued by CETESB (1990).

\section{MATERIALS AND METHODS}

The carbon dioxide is evolved during the breath process and it can be captured in an alkaline solution $(\mathrm{KOH})$ located in the lateral arm of the respirometric bottle. The amount of $\mathrm{CO}_{2}$ absorbed is then quantified by the residual $\mathrm{KOH}$ titration with a hydrochloric acid standard solution $(\mathrm{HCl})$, after the addition of barium chloride $\left(\mathrm{BaCl}_{2}\right)$ to precipitate carbonate ions. The levels of carbon dioxide accumulated can be calculated and be represented in function of the incubation time (Balba et al., 1998).

Two experiments were carried out, each one with four treatments to evaluate the biodegradability of the effluent in the respirometric bottle. The base inoculum was prepared with $100 \mathrm{~mL}$ of distilled water, $1.0 \mathrm{~mL}$ of Tween $80^{\circledR}$ (SYNTH - U.S.P.) and $50 \mathrm{~mL}$ of automotive lubricant oil (a mixture of mineral and half-synthetic oil without use). The resulting solution was transferred to a plastic bag of $5.0 \mathrm{~kg}$ with $3.0 \mathrm{~kg}$ of soil, from the Experimental Garden of the university, previously bolted and homogenized. The bag was closed and all its content was constantly mixed until forming a homogeneous mixture. Small perforations in the plastic bag had been made to allow the flow of microorganisms able to metabolizate this effluent. After that, this material was entered in soil near the Biochemistry and Microbiology Department (UNESP-Rio Claro) to a depth of approximately $15 \mathrm{~cm}$, remaining for a period of 15 days under weather and temperature existing during summer days.

The base inoculum was taken out after the necessary time. A mixture was prepared with 1.0 $\mathrm{kg}$ of base inoculum, $1500 \mathrm{~mL}$ of distilled water and $75 \mathrm{~mL}$ of the laboratorial surfactant Tween 
$80^{\circledR}$. This solution was homogenized with the aid of an agitator in continuous rotation (about 200 rpm) while the samples of $95 \mathrm{~mL}$ were transferred to Bartha flasks.

Bartha respirometers had been used the Technical Standard L6.350 issued by CETESB (1990). However the method was adapted to follow the biodegradation in aqueous medium. This respirometer consisted of a closed system, presenting two hardwired chambers, one with the effluent biodegradation in analysis and the other which had the alkaline solution able to identify the $\mathrm{CO}_{2}$ produced by the microbial breath with later quantification (Fig. 1).

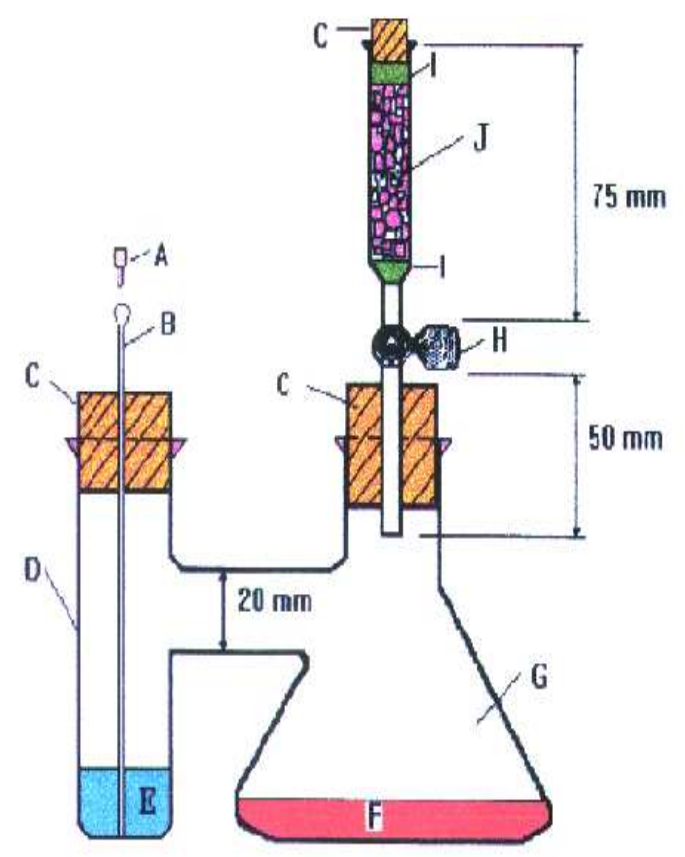

Figure 1 - Model of the system used for the respirometer. A: Cover the cannula; B: Cannula; C: Tight closed rubber cork; D: Lateral arm; E: Solution of KOH; F: Sample; G: Bottle cup of $350 \mathrm{~mL}$; H: Valve; I: Layer has supported; J: Filter of $\mathrm{CO}_{2}$.

The respirometer was maintained in a germination chamber type B.O.D. at $28{ }^{\circ} \mathrm{C}$ in a steady state. After each $\mathrm{KOH}$ sampling, the respirometer was aerated for 2 minutes. The air flow passed by the filter of $\mathrm{CO}_{2}$.

Mineral and half-synthetic lubricant oils were bought in a gas station located in the city of Rio Claro-SP, with the following specifications: Mineral Lubricant Oil was the Super F1 Plus SAE 25W/50 (API SJ) from Ipiranga and the Half-synthetic Lubricant Oil was the Magnatec SAE 10W/40 (API SL/CF) from Castrol.

Automotive lubricant oil that was used in the engines of automobiles was called as used lubricant oil and it was obtained from a lubrication center in the same city. This oil was a mixture of mineral and half-synthetic lubricants already used.

The composition of each treatment (T) in the experiments describes in the Table 1.

The incorporated $\mathrm{CO}_{2}$ allowed to evaluate the biodegradation of the different types of automotive lubricant oils in water systems, that is, the $\mathrm{CO}_{2}$ accumulation curve was used to determine which oil was more biodegradable. After each $\mathrm{CO}_{2}$ quantification, the respirometers were incubated again at $28{ }^{\circ} \mathrm{C}$ in a germination chamber type B.O.D. 
Table 1 - Respirometry Assays Composition.

\begin{tabular}{cl}
\hline T & Composition \\
\hline T1 & $95 \mathrm{~mL}$ of aqueous inoculum and $5.0 \mathrm{~mL}$ of destilled water \\
T2 & $95 \mathrm{~mL}$ of aqueous inoculum and $5.0 \mathrm{~mL}$ of half-synthetic lubricant oil \\
T3 & $95 \mathrm{~mL}$ of aqueous inoculum and $5.0 \mathrm{~mL}$ of mineral lubricant oil \\
T4 & $95 \mathrm{~mL}$ of aqueous inoculum and $5.0 \mathrm{~mL}$ of used lubricant oil \\
\hline
\end{tabular}

\section{RESULTS}

Figure 2 shows the $\mathrm{CO}_{2}$ accumulation curve for the four treatments carried out after 75 days of incubation. On the second experiment, which was a repetition of the first one, the Bartha respirometers had been submitted for 105 days of biodegradation (Fig. 3). Figures 2 and 3 show the mean of $\mathrm{CO}_{2}$ quantification obtained by respirometric assays that were in duplicate for each treatment. Also, the errors bars are presented on the quantifications of $\mathrm{CO}_{2}$.

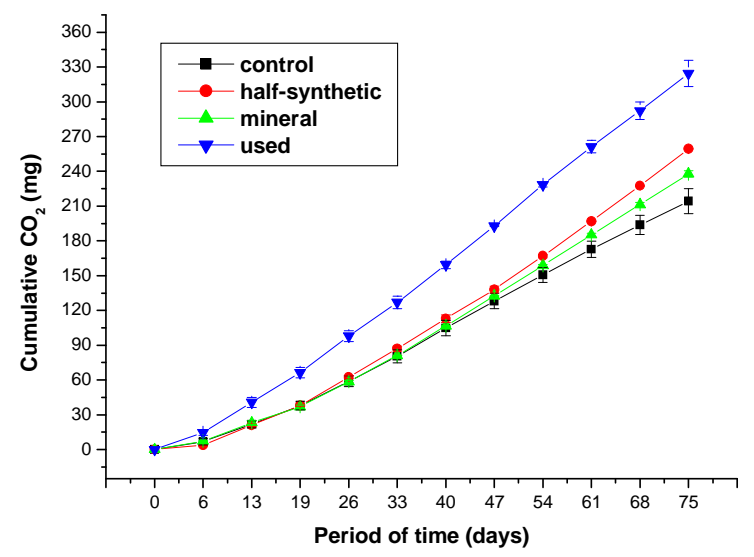

Figure 2 - Produced $\mathrm{CO}_{2}$ monitoring during biodegradability assays in 75 days.

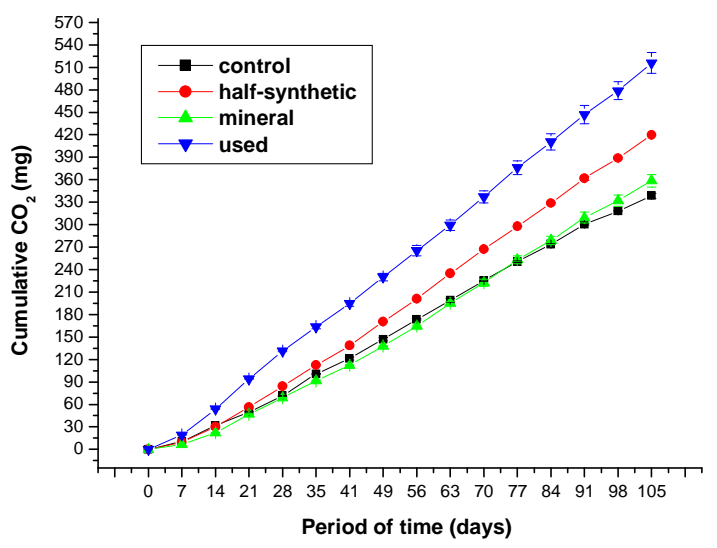

Figure 3 - Produced $\mathrm{CO}_{2}$ monitoring during biodegradability assays in 105 days. 
The results demonstrated that the microorganisms were able to metabolize the lubricant oils. Therefore, both assays containing the oils surpassed the $\mathrm{CO}_{2}$ amount produced by the control assay (T1). Figures 2 and 3 showed that used lubricant oil had better biodegradability showing a short adaptation period for the microorganism community to this effluent. Also, the assays with half-synthetic oil presented a higher $\mathrm{CO}_{2}$ mass and a shorter adaptation time by microorganisms when compared with the assays with mineral lubricant. Control treatment (T1), without lubricant oil, presented a very low $\mathrm{CO}_{2}$ production due to a reduced presence of effluent and organic substance in the prepared inoculum.

\section{DISCUSSION}

Figures 2 and 3 revealed that the control treatment (T1) presented a small $\mathrm{CO}_{2}$ production. This was due to the reduced amount of organic substance and lubricant oil in initial inoculum. The assays containing the automotive lubricant oils (T2, T3 and T4) presented a highest $\mathrm{CO}_{2}$ production in relation to the control assay. The microorganisms are able to assimilate the hydrocarbons as carbon source in their metabolism, thus liberating the carbon dioxide.

For $\mathrm{CO}_{2}$ quantifications in both the experiments, the curves of mineral and half-synthetic oils presented reduced advantage comparing to the control assay, therefore the microorganisms in the respirometers had a period of adaptation to the added composition. The half-synthetic lubricant curve (T2) had a smaller adaptation period for the microbial community in relation to the mineral one (T3). The used oil treatment (T4) presented a short adaptation period due to the capacity of being assimilated as carbon source by microorganisms.

The different adaptation periods of the lubricants could be easily observed in Figure 2, in which the used oil presents highest biodegradation compared to the control assay on the seventh day, halfsynthetic oil on the $40^{\text {th }}$ day and the mineral on $54^{\text {th }}$ day.

Figure 3 shows the assays following the same order as above. However, the differences of T4 and $\mathrm{T} 2$ in relation to the $\mathrm{T} 1$ at the end of the experiment were bigger than those in Figure 2.

In both Figures 2 and 3, the half-synthetic oil was more biodegradable than the mineral one. Bartz (1998) corroborated this result, stating that synthetic oils were used as raw materials to formulate biodegradable lubricants. Eisentraeger et al. (2002) demonstrated that generally, the synthetic lubricant composition was based on esters and which were more biodegradable in comparison with the substances present in mineral oils.

Figure 3 showed that the mineral oil curve remained below the control curve approximately until the $63^{\text {th }}$ day. This was due to toxic influence of the mineral based lubricant on the microbial community because of its toxicity. Similar result was found by Little et al. (2000), who observed that the toxicity could result in a bigger adaptation period by the microorganisms.

However, the automotive lubricant oil that presented greater $\mathrm{CO}_{2}$ production in the two experiments was the used oil. Thus, this showed that the process to which was submitted the lubricant in automobile engines modified its physical-chemistry characteristics. This was clearly reflected when a biodegradation study was carried out, because the high pressures and temperatures to which the oil was submitted during its use caused breaks in its carbonic chains and reduction in its viscosity, facilitating the microorganisms to degrade it.

Figures 2 and 3 showed that the $\mathrm{CO}_{2}$ cumulative production continued to increase. Thus, experiments should be carried out for longer period.

Respirometric experiments of Domingues and Bidoia (2006) on the biodegradation of different lubricant oils in soil showed the same result as of the present study. The oils biodegradation results in liquid medium demonstrated that a longer period for microorganisms' adaptation was found in mineral lubricant. Also, the used oil showed as the highest biodegradable lubricant.

\section{ACKNOWLEDGEMENTS}

Paulo Lopes acknowledges PRHANP/FINEP/MCT-CTPETRO, PRH-05, UNESP, Rio Claro, SP for financial support.

\section{RESUMO}

Avaliação da Biodegradação de Diferentes Tipos de Óleo Lubrificante em Meio Aquoso pela Norma 
Técnica L6.350 (CETESB, 1990), utiliza-se o processo respirométrico de Bartha e Pramer para acompanhar a biodegradação de diferentes tipos de óleo lubrificante automotivo adaptado ao meio aquoso. Para realização do experimento foram preparados um inóculo base e, posteriormente, um inóculo aquoso. Quatro tratamentos foram realizados em dois experimentos consecutivos: T1 (controle); T2 (óleo semi-sintético); T3 (óleo mineral); T4 (óleo usado). Dentre os resultados, obteve-se a seguinte ordem decrescente na produção de $\mathrm{CO}_{2}$ nos respirômetros: $\mathrm{T} 4>\mathrm{T} 2>\mathrm{T} 3$ $>\mathrm{T} 1$. Assim, o óleo lubrificante usado surgiu com maior biodegradabilidade, seguido do semisintético e do óleo mineral. Observou-se também que o lubrificante mineral apresentou maior período de adaptação comparado ao semisintético.

\section{REFERENCES}

AmbienteBrasil. (2006), Óleos Lubrificantes. Available in:

<http://www.ambientebrasil.com.br/composer.php3?b ase $=$ residuos/index.php3\&conteudo=./residuos/oleolu brificante.html>.

Atlas, R. M.; Horowitz, A.; Krichevsky, M. (1991), Response of microbial populations to environmental disturbance. Microbial Ecology, 22, 1157-1165.

Atlas, R. M. (1995), Bioremediation of Petroleum Pollutants. International Biodeterioration and Biodegradation, 35 (1-3), 317-327.

Balba, M.T.; Al-Awadhi, N.; Al-Daher, R. (1998), Bioremediation of oil-contaminated soil: microbiological methods for feasibility, assessment and field evaluation. Journal of Microbiological Methods, 32, 155-164.

Barhouch, G. P.; Fortes-Neto, P. (2004), Monitoramento da atividade microbiana em solo tratado, com resíduos provenientes de industrias petrolíferas. Disponible in: <http://www.unitau.br/prppg/inicient/veic/veicresumo sexa1.htm\#moni>.

Bartha, R.; Pramer, D. (1965), Features of a flask and method for measuring the persistence and biological effects of pesticides in soil. Soil Science, 100 (1), 6870.

Bartz, W. J. (1998), Lubricants and the environmental. Tribology International, 31 (1-3), 35-47.

Burns, K. A.; Garrity, S.; Jorissen, D.; MacPherson, J.; Stoelting, M.; Tierney, J.; Yelle-Simmons, L. (1994), The Galeta Oil Spill II: unexpected persistence of oil trapped in mangrove sediment. Estuarine Coastal and Shelf Science, 38, 349-364.
Cetesb. Companhia de Tecnologia e Saneamento Ambiental. (1990), Norma Técnica L. 6.350: Solos Determinação da Biodegradação de Resíduos: Método Respirométrico de Bartha. São Paulo: CETESB. 15 pp.

Cotton, F. O.; Wishman, M. L.; Goetzinger, J. W.; Reynolds, J. W. (1977), Analysis of 30 used motor oils. Hydrocarb. Proc., 22, 131-140.

Crivelaro, S. H. R. (2005), Associação de Borra Oleosa de Refinaria de Petróleo e Vinhaça visando a Biodegradação. Trabalho de Conclusão de Curso (Ecólogo), Universidade Estadual Paulista, Rio Claro, Brazil.

Domingues, R. F.; Bidoia, E. D. (2006), Efeito da bioestimulação na biodegradação do óleo lubrificante automotivo. Paper presented at $4^{\text {th }}$ Congresso de Iniciação Científica em Ciências Agrárias, Biológicas e Ambientais, 29-31 August, São Paulo, Brazil.

Eisentraeger, A.; Schmidt, M.; Murrenhoff, H.; Dott, W.; Hahn, S. (2002), Biodegradability testing of synthetic ester lubricants - effects of additives and usage. Chemosphere, 48, 89-96.

International Agency for Research on Cancer. (1983), Polynuclear aromatic hydrocarbons. 1. Chemical, environmental and experimental data. IARC Monogr. Eval. Carcinog. Risk Chem. Humans, 32, 1-16.

Little, E. E.; Cleveland, L.; Calfee, R.; Barron, M. G. (2000), Assessment of the photoenhanced toxicity of a weathered oil to the tide-water silverside. Environmental Toxicology and Chemistry, 19 (4), 926-932.

Oliveira, C. A.; Araújo, C. V. M.; Nascimento, R. B.; Strotmann, U. J; Silva, E. M. (2007), Utilisation of respirometry to assess organic matter reduction of effluents from the Camaçari industrial complex (BA, Brazil). Brazilian Archives of Biology and Technology, 50 (2), 311-319.

Régis, G.; Bidoia, E. D. (2005), Electrolytic treatment applied to the industrial effluent containing persistent wastes monitored by Bartha respirometric assays. Brazilian Archives of Biology and Technology, 48 (2), 319-325.

Rosato, Y. B. (1997), Biodegradação do Petróleo. InMicrobiologia Ambiental, eds. I.S. Melo; J.L. de Azevedo. Embrapa-CNPMA, Jaguariúna, pp. 307334.

Wright, M. A. (1992), Biodegradation of synthetic ester-based lubricants. Ph.D thesis. Cranfield Institute of Technology, Cranfield, United Kingdom.

Wright, M. A.; TAYLOR, F.; RANDLES, S. J.; BROWN, D. E.; HIGGINS, I. J. (1993), Biodegradation of a synthetic lubricant by Micrococcus roseus. Applied and Environmental Microbiology, 59 (4), 1072-1076.

Received: April 18, 2007; Revised: December 12, 2007; Accepted: March 27, 2009. 